"

$\because \because$ International Journal of Service Science and Management

$\therefore 2$

\title{
Scenario of Insertion Of Nutritionist Professionals in Health Services In Recife - Pernambuco
}

Anjos, A.M1; Oliveira, C.R.A2, Nascimento, D.F.R3, Lima, G.G.V4, Costa, M.P5, Souza, I.A6.

1,2,3,4,5Estudantes de Pós-Graduação do Programa de Residência Multiprofissional em Saúde Coletiva com Ênfase em Gestão de Redes de Atenção à Saúde - ESPPE; 6Pesquisadora do Programa de Pós-Graduação em Saúde Pública - FIOCRUZ.

\section{ABSTRACT}

Introduction: The topic of Human Resources has been occupying space in the researches related to Collective Health due to the importance of the workforce for health services in contributing to the execution of a health system based on Primary Care, such as the Brazilian National Health Service (SUS). Objective: To describe the scenario of the insertion of nutrition professionals in health services in Recife - Pernambuco. Methodology: This is a descriptive study with quantitative approach. This research was carried out with secondary data from the National Registry of Health Facilities (CNES). The population of study are nutrition professionals registered at CNES until December 2016 in the city of Recife, Pernambuco. To select the sample, the Epilnfo program was used. Thus, 219 out of 1077 nutritionists registered in the CNES database were selected to be part of the study, SPSS Statistics 22 was used for the presentation and analysis of the data. Results and Discussion: Among the 219 professionals analyzed, 95\% (207) are female and 5\% (12) are male. 15.52\% (34) of these are registered in other cities besides Recife. Regarding their workplace, $66.5 \%$ (145) worked in hospitals, $15.1 \%$ (33) in specialized services, $12.8 \%$ (28) in Primary Care services and $5.5 \%$ (12) in management, $86.7 \%$ (189) provide services to SUS. The average workload among the professionals studied was 43 hours per week in SUS services. The sample was quite heterogeneous, regarding the sex and the insertion scenario. Conclusion: Nutritionists in the municipality of Recife are mostly female. Regarding the insertion scenario, the hospital and specialized services area correspond to the main services where this professional is inserted, surpassing Primary Care services, requiring further studies that clarify this limbo of professionals in this level of attention.

Keywords: Collective Health; Human Resources in Nutrition; Epidemiology.
*Correspondence to Author:

Souza, I.A

Pesquisadora do Programa de Pós-Graduação em Saúde Pública - FIOCRUZ

How to cite this article:

Anjos, A.M; Oliveira, C.R.A, Nascimento, D.F.R, Lima, G.G.V, Costa, M.P, Souza, I.A.Scenario of Insertion Of Nutritionist Professionals in Health Services In Recife - Pernambuco.International Journal of Service Science and Management, 2018, $1: 2$

\section{eScîPub}

eSciPub LLC, Houston, TX USA.

Website: http://escipub.com/ 